\title{
Psoriasis and Its Association with Various Biochemical Parameters - A Clinico-Epidemiological Study
}

\author{
Bhagya Rekha Manchiryala ${ }^{1}$, Usha Rani Tirupathi ${ }^{2}$, Anand T. ${ }^{3}$ \\ ${ }^{1}$ Department of DVL, Kakatiya Medical College, Warangal, Telangana, India. ${ }^{2}$ Department of DVL, Kakatiya Medical \\ College, Warangal, Telangana, India. ${ }^{3}$ Department of DVL, Kakatiya Medical College, Warangal, Telangana, India.
}

\section{ABSTRACT}

\section{BACKGROUND}

Psoriasis is a chronic, genetically determined, inflammatory and proliferative disease of the skin and joints. It is associated with several co-morbidities including psoriatic arthritis, decreased quality of life, depression, increased cardiovascular risk, type 2 diabetes mellitus, hypertension, metabolic syndrome, cancer and Crohn's disease. Patients with metabolic syndrome are at a significantly increased risk of developing cardiovascular morbidity and mortality. Increased rates of depression in patients with psoriasis may be another factor leading to increased risk of cardiovascular disease.

\section{METHODS}

The study was conducted among 100 cases of psoriasis of either sex attending Dermatology, Venereology, Leprosy OPD at MGM Hospital, Warangal, during the period of January 2015 to June 2016.

\section{RESULTS}

A total of 100 cases of psoriasis and 100 age and sex matched controls were recruited. Detailed history, thorough physical \& clinical examination and lab investigations were carried out. The severity of psoriasis was assessed using the PASI score. The results obtained have been depicted in tabular and graph format. Statistical analysis of the cases and controls was carried out.

\section{CONCLUSIONS}

The present study concluded that psoriatic patients were not at any increased risk of cardiovascular co-morbidities as we did not note any significant correlation between the derangements of lipid parameters and occurrence of co-existent diabetes or hypertension. Another important conclusion deducted from the present study was that there was no discrepancy in the parameters of lipid profile with the severity of psoriasis.

\section{KEY WORDS}

Metabolic Syndrome, Serum Uric Acid, Lipid Profile, Psoriatic Arthritis
Corresponding Author: Bhagya Rekha Manchiryala, H. No. 6-2-83, Kakaji Colony, Hanamkonda, Warangal, Telangana, India.

E-mail:dr.sbrekha@gmail.com

DOI: $10.14260 / j e m d s / 2020 / 194$

Financial or Other Competing Interests: None.

How to Cite This Article:

Manchiryala BR, Tirupathi UR, Anand T. Psoriasis and its association with various biochemical parameters- a clinicoepidemiological study. J. Evolution Med.

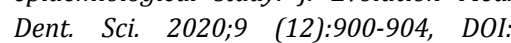
$10.14260 /$ jemds/2020/194

Submission 03-10-2019, Peer Review 26-02-2020, Acceptance 04-03-2020, Published 23-03-2020.
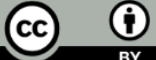


\section{BACKGROUND}

Psoriasis is a chronic, inflammatory and proliferative condition of the skin, in which both genetic and environmental influences have a critical role. ${ }^{1}$ The aetiology of psoriasis is unknown but genetic, metabolic and immunological mechanisms have been proposed. Activated Tcells are believed to be the primary modulators in the pathogenesis of psoriasis. ${ }^{2,3}$ It is characterized by chronic, sharply demarcated dull-red, scaly plaques, particularly on the extensor prominences and the scalp. It has a bimodal distribution of age of onset being most common in the second to fourth decade of life ${ }^{1}$. Several studies confirm that psoriasis worsen in winter and improves in summer. ${ }^{1}$ Psoriasis is associated with several co-morbidities including decreased quality of life, increased cardiovascular risk, type-2 diabetes mellitus, hypertension, metabolic syndrome, cancer and Crohn's disease. ${ }^{4,5}$ It has been suggested that psoriasis is associated with metabolic syndrome, but there have been very few studies on the association between psoriasis and diabetes. As diabetes is an independent risk factor for the development of cardiovascular disease, ${ }^{6}$ its association with psoriasis is of importance.

Elevated serum uric acid levels are a frequent finding in psoriasis. It seems a convincing idea that the rapid epidermal turnover in psoriasis might lead to an increased purine breakdown and may thus influence the serum uric acid levels. ${ }^{7}$ Many studies of the past have especially identified a direct association between serum uric acid levels and psoriatic arthropathy. Scaling from the surface of the lesion in psoriasis may be related to lipid disorders in the epidermis and in the serum. ${ }^{8}$ Serum lipid level abnormalities may be the reason for increased risk of atherosclerosis in psoriasis. ${ }^{9}$ Evidence suggests that chronic inflammation, a characteristic feature of psoriasis, per se may play a role in the initiation and progress of dyslipidaemia and atherosclerosis.

Diagnosis of psoriasis is usually made on clinical grounds alone and rarely requires a skin biopsy. Psoriasis Area Severity Index (PASI) is a useful tool for monitoring the response of psoriasis to any therapeutic regimen. ${ }^{1}$ This system provides an objective tool for the evaluation of psoriasis. Psoriasis is usually a lifelong disease with variable periods of spontaneous remissions and exacerbations. However, the course and progress in a particular patient are unpredictable. The present study is done to know further about the clinical and epidemiological profile of the disease and to assess its collaboration with lipid profile, diabetes status which in turn act as risk factors for cardiovascular disease in these patients. Further correlation of serum uric acid levels with severity of the disease is assessed.

\section{METHODS}

The present study comprised of 100 newly diagnosed cases of psoriasis of either sex visiting OPD of MGM Hospital, Warangal during the period of January 2015 to June 2016 (18 months). This was a cross-sectional study with purposive sampling. Newly diagnosed cases of psoriasis who haven't started either topical or systemic treatment for psoriasis are only included for the study as they may interfere with lipid profile or blood sugars or serum uric acid levels. After obtaining informed consent, detailed history was taken, and thorough clinical examination was carried out and the clinical data was recorded as per the proforma. The available case records were scrutinized to collect any information regarding pre-existing illnesses. Routine haematological investigations like fasting blood sugar, fasting lipid profile, serum uric acid levels were carried out by taking $10 \mathrm{ml}$ venous blood from all pupil. Supine blood pressure of all patients was recorded. PASI (Psoriasis Area Severity Index) scoring was done on all the patients and were categorized into mild, moderate and severe. PASI $<3$ as mild, $3-10$ as moderate, $>10$ as severe.

Statistical analysis was carried out using ANOVA (Analysis of Variance), Chi-square/2x3 Fisher Exact test to find the relevance of study parameters on categorical scale.

\section{RESULTS}

Out of 100 cases that were selected for the study, 71 were males and 29 were females. The ratio of males and females in our study is 2.4:1 and controls are 2.2:1._The distribution of age in our study ranged from 18-75 years. Maximum number of patients belonged to age group of $41-50$ years (28\%) whereas it was only $3 \%$ in $13-20$ years and $2 \%$ in $71-80$ years. Based on PASI, severity of psoriasis was mild in $3 \%$, moderate in $55 \%$ and severe in $42 \%$ of cases. Of the 100 patients that were selected for the study, 12 patients had psoriatic arthritis and $88 \%$ of the patients did not show any joint involvement. Diabetes mellitus was seen in 19\% of the cases while in controls it was $12 \%$. This was not a statistically relevant association. ( $\mathrm{p}$ value: 0.171). Hypertension was noted in $15 \%$ of the cases while in controls it was $14 \%$. This was not a statistically considerable association. ( $\mathrm{p}$ value: $0.8408)$.

$20 \%$ of patients had elevated serum uric acid levels while $17 \%$ of the controls showed elevated levels of serum uric acid. Thus, no association was found between increase in uric acid levels and psoriasis (p value: 0.584). Further, the association between the prevalence of diabetes and abnormalities in the lipid parameters, prevalence of hypertension and abnormalities in lipid parameters was not found to be statistically significant. There was no association noted between the fasting blood glucose level and severity of psoriasis ( $p$ value: 0.403 ).

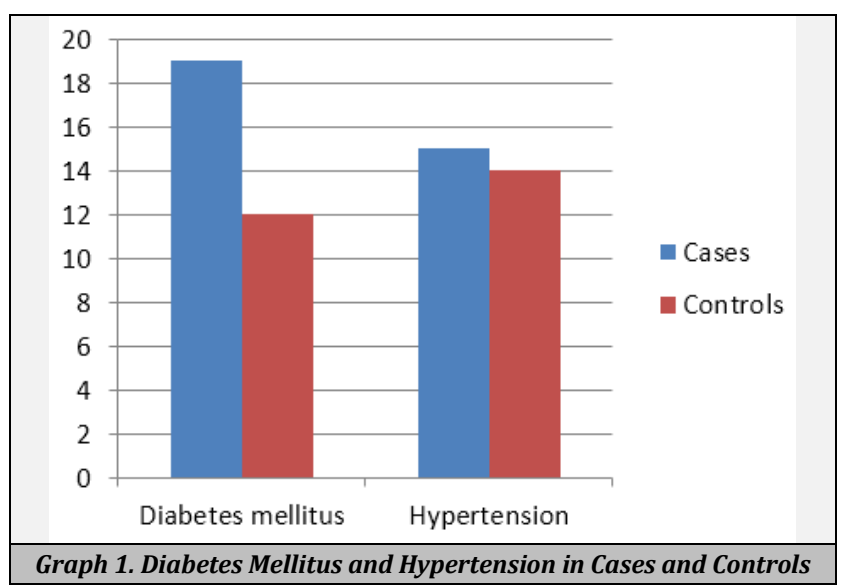




\begin{tabular}{|cccc|}
\hline Psoriatic & No. of Patients & \multicolumn{2}{c|}{ Serum Uric Acid } \\
Arthritis & $(\mathbf{n = 1 0 0 )}$ & $<\mathbf{6 . 0} \mathbf{~ m g / d L}$ & $>\mathbf{6 . 0} \mathbf{~ m g} / \mathbf{d L}$ \\
Yes & 12 & $11(91.66 \%)$ & $1(8.33 \%)$ \\
No & 88 & $70(79.54 \%)$ & $18(20.45 \%)$ \\
Total & 100 & $83(83.0 \%)$ & $17(17.0 \%)$ \\
\hline \multicolumn{3}{c}{ Table 1. Variation of Uric Acid Levels with } \\
& Prevalence of Psoriatic Arthritis \\
\hline
\end{tabular}

\begin{tabular}{|c|c|c|c|c|}
\hline $\begin{array}{c}\text { Lipid } \\
\text { Parameters }\end{array}$ & Criteria & $\begin{array}{c}\text { Cases } \\
(n=100)\end{array}$ & $\begin{array}{l}\text { Controls } \\
(n=100)\end{array}$ & $\mathbf{p}$ \\
\hline Total cholesterol & $\begin{array}{l}<225 \mathrm{mg} / \mathrm{dL} \\
>225 \mathrm{mg} / \mathrm{dL}\end{array}$ & $\begin{array}{l}89(89.0 \%) \\
11(11.0 \%)\end{array}$ & $\begin{array}{c}91(91.0 \%) \\
9(9.0 \%)\end{array}$ & 0.637 \\
\hline Serum Triglycerides & $\begin{array}{l}<170 \mathrm{mg} / \mathrm{dL} \\
>170 \mathrm{mg} / \mathrm{dL}\end{array}$ & $\begin{array}{l}53(53.0 \%) \\
47(47.0 \%)\end{array}$ & $\begin{array}{l}64(64.0 \%) \\
36(36.0 \%)\end{array}$ & 0.114 \\
\hline HDL & $\begin{array}{l}<35 \mathrm{mg} / \mathrm{dL} \\
>35 \mathrm{mg} / \mathrm{dL}\end{array}$ & $\begin{array}{l}21(21.0 \%) \\
79(79.0 \%)\end{array}$ & $\begin{array}{l}25(25.0 \%) \\
75(75.0 \%)\end{array}$ & 0.501 \\
\hline VLDL & $\begin{array}{l}<40 \mathrm{mg} / \mathrm{dL} \\
>40 \mathrm{mg} / \mathrm{dL}\end{array}$ & $\begin{array}{l}63(63.0 \%) \\
37(37.0 \%)\end{array}$ & $\begin{array}{l}66(66.0 \%) \\
34(34.0 \%)\end{array}$ & 0.726 \\
\hline LDL & $\begin{array}{l}<150 \mathrm{mg} / \mathrm{dL} \\
>150 \mathrm{mg} / \mathrm{dL}\end{array}$ & $\begin{array}{l}89(89.0 \%) \\
11(11.0 \%)\end{array}$ & $\begin{array}{c}92(92.0 \%) \\
8(8.0 \%)\end{array}$ & 0.469 \\
\hline Tabl & 2. Lipid Pro & e in Cases & d Controls & \\
\hline
\end{tabular}

\begin{tabular}{|c|c|c|c|c|}
\hline $\begin{array}{c}\text { Lipid } \\
\text { Parameters }\end{array}$ & Criteria & $\begin{array}{c}\text { Cases } \\
(n=100)\end{array}$ & $\begin{array}{l}\text { Controls } \\
(n=100)\end{array}$ & $\mathbf{p}$ \\
\hline Total cholesterol & $\begin{array}{l}<225 \mathrm{mg} / \mathrm{dL} \\
>225 \mathrm{mg} / \mathrm{dL}\end{array}$ & $\begin{array}{l}89(89.0 \%) \\
11(11.0 \%)\end{array}$ & $\begin{array}{c}91(91.0 \%) \\
9(9.0 \%)\end{array}$ & 0.637 \\
\hline $\begin{array}{c}\text { Serum } \\
\text { Triglycerides }\end{array}$ & $\begin{array}{l}<170 \mathrm{mg} / \mathrm{dL} \\
>170 \mathrm{mg} / \mathrm{dL}\end{array}$ & $\begin{array}{l}53(53.0 \%) \\
47(47.0 \%)\end{array}$ & $\begin{array}{l}64(64.0 \%) \\
36(36.0 \%)\end{array}$ & 0.114 \\
\hline HDL & $\begin{array}{l}<35 \mathrm{mg} / \mathrm{dL} \\
>35 \mathrm{mg} / \mathrm{dL}\end{array}$ & $\begin{array}{l}21(21.0 \%) \\
79(79.0 \%)\end{array}$ & $\begin{array}{l}25(25.0 \%) \\
75(75.0 \%)\end{array}$ & 0.501 \\
\hline VLDL & $\begin{array}{l}<40 \mathrm{mg} / \mathrm{dL} \\
>40 \mathrm{mg} / \mathrm{dL}\end{array}$ & $\begin{array}{l}63(63.0 \%) \\
37(37.0 \%)\end{array}$ & $\begin{array}{l}66(66.0 \%) \\
34(34.0 \%)\end{array}$ & 0.726 \\
\hline LDL & $\begin{array}{l}<150 \mathrm{mg} / \mathrm{dL} \\
>150 \mathrm{mg} / \mathrm{dL}\end{array}$ & $\begin{array}{l}89(89.0 \%) \\
11(11.0 \%)\end{array}$ & $\begin{array}{c}92(92.0 \%) \\
8(8.0 \%)\end{array}$ & 0.469 \\
\hline Serum Uric Acid & $\begin{array}{l}<6.0 \mathrm{mg} / \mathrm{dL} \\
>6.0 \mathrm{mg} / \mathrm{dL}\end{array}$ & $\begin{array}{l}80(80.0 \%) \\
20(20.0 \%)\end{array}$ & $\begin{array}{l}83(83.0 \%) \\
17(17.0 \%)\end{array}$ & 0.584 \\
\hline $\begin{array}{c}\text { Hypertension } \\
\text { diabetes mellitus }\end{array}$ & $\begin{array}{c}>130 / 90 \mathrm{~mm} \\
\text { of } \mathrm{Hg} \\
>100 \mathrm{mg} / \mathrm{dL}\end{array}$ & $15(15.0 \%)$ & $14(14.0 \%)$ & 0.8408 \\
\hline Table & 3. Various $P$ & ameters in & ses and Co & \\
\hline
\end{tabular}

\begin{tabular}{|ccccc|}
\hline Variables & Mild & $\begin{array}{c}\text { PASI } \\
\text { Moderate }\end{array}$ & Severe & p \\
Age in years & $36.00 \pm 6.56$ & $44.82 \pm 12.33$ & $40.74 \pm 13.86$ & 0.203 \\
FBS (mg/dL) & $87.33 \pm 7.57$ & $92.31 \pm 20.12$ & $96.76 \pm 22.22$ & 0.498 \\
Total cholesterol (mg/dL) & $181.00 \pm 43.00$ & $180.42 \pm 35.87$ & $187.11 \pm 39.80$ & 0.684 \\
Triglycerides (mg/dL) & $254.00 \pm 168.02$ & $191.69 \pm 92.21$ & $172.69 \pm 91.02$ & 0.275 \\
HDL (mg/dL) & $38.67 \pm 5.51$ & $39.07 \pm 6.37$ & $38.92 \pm 7.06$ & 0.991 \\
VLDL (mg/dL) & $53.33 \pm 30.99$ & $36.89 \pm 16.51$ & $32.66 \pm 13.74$ & $0.069+$ \\
LDL (mg/dL) & $88.00 \pm 16.46$ & $104.84 \pm 25.56$ & $113.78 \pm 33.42$ & 0.161 \\
Uric acid (mg/dL) & $5.17 \pm 1.06$ & $5.08 \pm 1.11$ & $4.81 \pm 1.24$ & 0.511 \\
\hline Table 4. Comparison of Prevalence of diabetes Mellitus, \\
Abnormal Lipid Profile and Abnormal Uric Acid \\
According to Different Levels of PASI Scores \\
\hline \multicolumn{5}{c}{} \\
\hline
\end{tabular}

\section{DISCUSSION}

Psoriasis is a paradigm of a chronic and relapsing inflammatory skin disease which so far was supposed to be restricted to the skin with the exception of Psoriatic arthritis. The systemic inflammation present in psoriasis, various systemic treatments for psoriasis and an increased prevalence of unhealthy lifestyle factors may all contribute to this unfavourable cardiovascular risk profile. This study was undertaken to study one such debatable associationassociation with abnormalities in lipid profile, blood glucose levels and prevalence of hypertension which collectively constitute the so-called metabolic syndrome. A raised male preponderance was noted in our study with 71 male and 29 female patients with a male to female ratio of $2.4: 1$, which is in accordance with the findings noted in other published studies. $^{10,11,12}$ the ratio in controls was 2.2:1. Psoriasis was noted predominantly (28\%) in the age group of 41-50 years. In our study, $3 \%$ patients had mild psoriasis (PASI $<3$ ), $55 \%$ of patients had psoriasis of moderate severity (PASI 3-10) whereas $42 \%$ had severe type (PASI $>10$ ). Thus, $58 \%$ of patients found to have PASI score less than 10, which show resemblance with other studies. Rao et al revealed PASI ranged from 0.5-30 (mean- 10.22). ${ }^{13}$ Psoriatic arthropathy was noted in 12 of our patient's i.e., $12 \%$. Prasad et al, ${ }^{14}$ Bedi et $\mathrm{al}^{11}$ and Kumar et $\mathrm{al}^{15}$ in their study on Indian patients showed prevalence of psoriatic arthritis to be $8.47 \%, 10 \%$ and $8.7 \%$ respectively. Thus, our findings correlated with those of the above studies.

\section{diabetes Mellitus}

In our study $19 \%$ of the cases were diabetic while only $12 \%$ of the controls had diabetes mellitus with a p-value 0.171 . These findings were congruent with the studies done by Alexander et al, ${ }^{16}$ Sundaram ${ }^{17}$ on Indian patients. However, certain authors from Western countries reported contradictory finding. Niemann et $\mathrm{al}^{18}$ Sommer et $\mathrm{al}^{1}{ }^{19}$ Shapiro et $\mathrm{al}^{20}$ and Cohen et al have all noted a rise in the occurrence of diabetes in patients with psoriasis. The distribution of diabetes in psoriasis patients according to the severity of disease was as follows: mild disease $(0 \%)$, moderate disease $(14.5 \%)$ and severe disease $(23.8 \%)$. There was no statistically significant correlation noted between the prevalence of diabetes mellitus and the severity of the disease ( $p$ value-0.403). Lee et al ${ }^{21}$ revealed a mild disease in $10.5 \%$ and severe disease in $18.2 \%$ of cases.

\section{Uric Acid Levels}

Increased levels of uric acid were found in $20 \%$ of psoriasis patients while in controls, mildly increased levels were seen in $17 \%$ patients. The mean value of uric acid in cases was $4.97 \mathrm{mg} / \mathrm{dL}$ while the mean value in controls was 4.67 $\mathrm{mg} / \mathrm{dL}$. This association was found to be of suggestive significance ( $p$ value-0.078). Jain et al revealed a mean value of uric acid in cases as $7.0 \mathrm{mg} / \mathrm{dL}$ when compared to controls as $4.1 \mathrm{mg} / \mathrm{dL}$. Our results were consistent with those of Lambert and Wright ${ }^{22}$ who found a high prevalence of serum uric acid values above normal, but a mean value inside the normal range. The study on Indian patients by Prasad et al ${ }^{14}$ revealed an increase in serum uric acid levels in $45 \%$ of the patients. However, the mean values were within the normal range. A study of 132 psoriatic patients in India by Vermaet $\mathrm{al}^{23}$ revealed that high serum uric acid levels were present in $26.6 \%$ of the patients.

\section{Uric acid Levels with PASI}

The mean value of uric acid in patients with mild, moderate and severe disease was 5.17, 5.08 and $4.81 \mathrm{mg} / \mathrm{dL}$ respectively. In our study, no significant association was found between the severity of psoriasis and the levels of uric acid ( $p$ value-0.511). This was consistent with the study of 50 psoriatic patients by Ramesh Chand et al, ${ }^{24}$ where they found that 7 patients had elevated serum uric acid levels without any relation to the extent of skin involvement. Another study by Brenner et al also concluded that there is no relationship between the frequency of hyperuricemia and the extent of psoriatic skin involvement.

\section{Uric Acid Levels with Psoriatic Arthritis}

Amongst patients with psoriatic arthritis, 91.66\% revealed a normal level of uric acid. Thus, psoriatic arthritis was not 
significantly associated with increase in levels of uric acid ( $p$ value-0.315). These findings were consistent with that of Anuja et $\mathrm{al}^{25}$ on Indian patients, similar results were also noted by Lambert and Wright ${ }^{22}$ in their study on western patients.

\section{Hypertension}

In the present study, prevalence of hypertension in psoriatic patients was $15 \%$ and in controls was $14 \%$. Thus, indicating no statistically significant correlation with a p-value of 0.8408 . However, no correlation was noted between severity of the disease and the prevalence of hypertension ( $\mathrm{p}$ value0.385). Our findings were compatible with that of Alexander et $\mathrm{al}^{16}$ on Indian patients which showed a prevalence of hypertension in $8.1 \%$ of psoriasis patients. This however was in contrast to many studies published in western literature. Cohen et $\mathrm{al}^{20}$ reported significantly high prevalence of hypertension in psoriasis patients than controls $(38.8 \%$ and $29.1 \%$ respectively).

\section{Lipid Levels}

In the present study, $89 \%$ of the cases of psoriasis had normal levels of serum cholesterol as compared to $91 \%$ of controls. Hence, the difference in the cholesterol levels between cases and control were not statistically significant ( $p$ value-0.637). In a study done by Sunitha et $a{ }^{2}{ }^{26}$ mean cholesterol levels in cases was $160.38 \mathrm{mg} / \mathrm{dL}$ when compared to controls as $145.33 \mathrm{mg} / \mathrm{dL}$ ( $\mathrm{p}$ value-0.02). Whereas in studies by Mallbris et al. ${ }^{27}$ Rocha-Pereira et al, ${ }^{28}$ and Piskin et $\mathrm{al}^{29}$ total serum cholesterol levels were elevated. The mean value of serum triglycerides in cases was 185.58 which was considerably higher than the mean value in controls which was 149.46 ( $\mathrm{p}$ value<0.001). Also, in studies by RochaPereira et al., Javidi et al., noted elevated levels of serum triglycerides. The cases and controls showed a mean value of HDL as 39.00 and 39.68 respectively, thus representing no statistically significant association ( $p$ value-0.707).These results were congruent with that of Piskin et al. The cases and controls showed a mean value of VLDL as 35.63 and 33.83 respectively, thus showing no statistically significant equivalence between cases and controls ( $p$ value-0.339). Mean LDL values in cases was 108.03 while in controls was 114.41. This alliance was not found to be statistically remarkable ( $\mathrm{p}$ value-0.097). These results were in accordance with the studies of Rocha-Pereira et al, Uyanik. ${ }^{30}$

\section{CONCLUSIONS}

Recent review of literature suggests an association of metabolic syndrome with psoriasis. Strong associations with dyslipidaemia, obesity, diabetes and increased cardiovascular morbidities apart from common co-morbidities like psoriatic arthritis and depressive disorder have been reported. 19\% of the psoriasis patients had concomitant diabetes while $12 \%$ of the controls also had diabetes. However, no interaction was found between occurrence of diabetes mellitus and severity of the disease. Thus, we could conclude that diabetes in these patients is an incident finding and is not related to the severity of the disease.
$15 \%$ of the patients had coexistent hypertension and psoriasis as compared to $14 \%$ of controls. $20 \%$ of the patients had an increase in serum uric acid levels as compared to $17 \%$ of controls. This association was found to be of suggestive significance. However, no correlation was noted between the serum uric acid levels and the severity of the disease. Further, serum uric acid levels were not found to be significantly elevated in patients with psoriatic arthritis. Thus, we concluded that occasional elevation in serum uric acid in psoriasis patients is also an independent finding and is not related to the disease process or to the severity of the disease.

Amongst the various lipid parameters, significant rise was noted in serum triglycerides only while other parameters like HDL, VLDL, HDL and total cholesterol had no statistically significant association. Further, there was no comparability between the severity of the disease and lipid profile abnormality. In addition, we did not note any significant correlation between the derangements of lipid parameters and occurrence of co-existent diabetes or hypertension. There was also no influence of age of onset of the disease with the abnormality in lipid parameters. Thus, we concluded from our study that psoriasis patients were not at any increased risk of cardiovascular abnormalities.

Our study denies association of psoriasis with metabolic syndrome done on Indian patients. But many studies from the Western countries show such affiliation which can be interpreted on the basis of difference in the lifestyle between westerners and Indians. In addition, there is higher prevalence of coexistent risk factors like smoking and alcohol intake in the west which may contribute to morbidity and prevalence of metabolic syndrome. Furthermore, ours is the first study being conducted on newly diagnosed patients of psoriasis before initiating any therapy.

\section{REFERENCES}

[1] Griffiths CEM, Camp RDR, Barker JNWN. Psoriasis. In: Burns T, Breathnach S, Cox N, et al. eds. Rook's Textbook of Dermatology. $7^{\text {th }}$ edn. Oxford: Blackwell Science 2005: p. 35.1-35.69.

[2] Nograles KE, Davidovici B, Krueger JG. New insights in the immunologic basis of psoriasis. Semin Cutan Med Surg 2010;29 (1):3-9.

[3] Krueger G, Ellis CN. Psoriasis-recent advances in understanding its pathogenesis and treatment. J Am Acad Dermatol 2005; 53 (1 Suppl 1):S94-100.

[4] Traub M, Marshall K. Psoriasis - Pathophysiology, conventional and alternative approaches to treatment. Alternative Medicine Review 2007; 12 (4):319-30.

[5] Puig-Sanz L. Psoriasis, a systemic disease? Actas Dermosifiliogr 2007; 98(6):396-402.

[6] Kaye JA, Li L, Jick SS. Incidence of risk factors for myocardial infarction and other vascular diseases in patients with psoriasis. Br J Dermatol 2008; 159(4):895902.

[7] Brenner W, Gschnait F. Serum uric acid levels in untreated and PUVA-treated patients with psoriasis. Acta Derm Venereol Suppl (Stockh) 1979; 87:41-2.

[8] Javidi Z, Meibodi NT, Nahidi Y. Serum lipid abnormalities and psoriasis. Indian J Dermatology 2007; 52(2):89-92. 
[9] Seckin D, Tokgozoglu L, Akkaya S. Are lipoprotein profile and lipoprotein a levels altered in men with psoriasis? J Am Acad Dermatol 1994; 31(3 Pt 1):445-9.

[10] Kaur I, Handa S, Kumar B. Natural history of psoriasis: a study from the Indian subcontinent. J Dermatol 1997; 24(4):230-4.

[11] Bedi TR. Clinical profile of psoriasis in North India. Indian J Dermatol Venereol Leprol 1995; 61(4):202-5.

[12] Mehta TK, Shah RN, Marquis LA. A study of 300 cases of psoriasis. Indian J Dermatol Venereol Leprol 1976; 42(2):67-70.

[13] Aruna C, Rao GV, Ramanamurthy P, et al. Prevalence of metabolic syndrome in patients with psoriasis: a hospital-based case-control study from a tertiary care center in Andhra Pradesh. J NTR Univ Health Sci 2016; 5(1):13-16.

[14] Prasad PVS, Bikku B, Kaviarasan PK, et al. A clinical study of psoriatic arthropathy. Indian J Dermatol Venereol Leprol 2007; 73(3):166-70.

[15] Kumar R, Sharma A, Dogra S. Prevalence and clinical patterns of psoriatic arthritis in Indian patients with psoriasis. Indian J Dermatol Venereol Leprol 2014; 80(1):15-23.

[16] Alexander E, Pinto J, Pal GS, et al. Disease concomitance in psoriasis: a clinical study of 61 cases. Indian J Dermatol Venereol Leprol 1995; 61(4):202-5.

[17] Sundharam JA, Singh R, Agarwal PS. Psoriasis and diabetes mellitus. Indian J Dermatol Venereol Leprol 1980; 46:158-62.

[18] Neimann AL, Shin DB, Wang X, et al. Prevalence of cardiovascular risk factors in patients with psoriasis. J Am Acad Dermatol 2006; 55(5):829-35.

[19] Sommer DM, Jenisch S, Suchan $M$, et al. Increased prevalence of the metabolic syndrome in patients with moderate to severe psoriasis. Arch Dermatol Res 2006; 298 (7):321-8.
[20] Shapiro J, Cohen AD, David M, et al. The association between psoriasis, diabetes mellitus and atherosclerosis in Israel: a case-control study. J Am Acad Dermatol 2007; 56 (4):629-34.

[21] Lee MS, Lin RY, Lai MS. Increased risk of diabetes mellitus in relation to severity of psoriasis, concomitant medication, and comorbidity: A Nationwide PopulationBased Cohort Study. J Am Acad of Dermatol 2014; 70(4):691-8.

[22] Lambert JR, Wright V. Serum uric acid levels in psoriatic arthritis. Ann Rheuma Dis 1977; 36(3):264-7.

[23] Verma KC, Bhargava NC, Chaudhry SD, et al. Psoriasis: a clinical and some biochemical investigative study. Indian J Dermatol Venereol Leprol 1979; 45(2):95-9.

[24] Chand R, Reddy BSNV, Sehgal VN, et al. Serum uric acid, Calcium and Phosphorus in Psoriasis. Indian Journal of Dermatology, Venereology and Leprology 1983; 49(4):150-2.

[25] Anuja EG, Sarojini PA. Psoriatic arthropathy: a clinical and biochemical study. Indian J Dermatol Venereol Leprol 1997; 63(6):357-60.

[26] Sunitha S, Rajappa M, Thappa DM, et al. Comprehensive lipid tetrad index, atherogenic index and lipid peroxidation: surrogate markers for increased cardiovascular risk in psoriasis. Indian Journal of Dermatology 2015;81(5):464-71.

[27] Mallbris L, Granath F, Hamsten A, et al. Psoriasis is associated with lipid abnormalities at the onset of skin disease. J Am Acad Dermatol 2006; 54(4):614-21.

[28] Rocha-Pereira P, Santos-Silva A, Rebelo I, et al. Dyslipidemia and oxidative stress in mild and severe psoriasis as a risk for cardiovascular disease. Clin Chim Acta 2001; 303(1-2):33-9.

[29] Piskin S, Gurkok F, Ekuklu G, et al. Serum lipid levels in Psoriasis. Yonsei Med J 2003; 44(1):24-6.

[30] Uyanik BS, Ari Z, Onur E, et al. Serum lipids and apolipoproteins in patients with Psoriasis. Clin Chem Lab Med 2002; 40(1):65-8. 